\title{
Role of salicylic acid in alleviating oxidative damage in rice roots (Oryza sativa) subjected to cadmium stress
}

\author{
B. Guo ${ }^{\text {a,e }}$, Y.C. Liang ${ }^{\text {b, } *}$, Y.G. Zhu ${ }^{\text {c,* }}$, F.J. Zhao ${ }^{\text {d }}$ \\ ${ }^{a}$ Department of Plant Nutrition, College of Natural Resources and Environmental Sciences, Nanjing Agricultural University, \\ Nanjing 210095, PR China \\ ${ }^{\mathrm{b}}$ Institute of Soil and Fertilizer, Ministry of Agriculture Key Laboratory of Plant Nutrition and Nutrient Cycling, Chinese Academy of Agricultural \\ Sciences, South Zhongguancun Street No. 12, Beijing 100081, PR China \\ ${ }^{\mathrm{c}}$ Research Center for Eco-environmental Sciences, Chinese Academy of Sciences, Beijing 100085, PR China \\ ${ }^{\mathrm{d}}$ Agriculture and Environment Division, Rothamsted Research, Harpenden, Herts AL5 2JQ, United Kingdom \\ ${ }^{\mathrm{e}}$ Institute of Soil and Fertilizer, Zhejiang Academy of Agricultural Sciences, Hangzhou, 310021, China
}

Received 27 June 2006; received in revised form 6 September 2006; accepted 7 September 2006

\begin{abstract}
Pretreatment with SA enhanced the antioxidant defense activities in Cd-stressed rice, thus alleviating Cd-induced oxidative damage and enhancing $C d$ tolerance.
\end{abstract}

\begin{abstract}
Time-dependent changes in enzymatic and non-enzymatic antioxidants, and lipid peroxidation were investigated in roots of rice (Oryza sativa) grown hydroponically with $\mathrm{Cd}$, with or without pretreatment of salicylic acid (SA). Exposure to $50 \mu \mathrm{M}$ Cd significantly decreased root growth, and activities of superoxide dismutase (SOD), catalase (CAT) and peroxidase (POD), but increased the concentrations of $\mathrm{H}_{2} \mathrm{O}_{2}$, malondialdehyde (MDA), ascorbic acid (AsA), glutathione (GSH) and non-protein thiols (NPT). However, pretreatment with $10 \mu \mathrm{M} \mathrm{SA}$ enhanced the activities of antioxidant enzymes and the concentrations of non-enzymatic antioxidants, but lowered the concentrations of $\mathrm{H}_{2} \mathrm{O}_{2}$ and $\mathrm{MDA}$ in the Cd-stressed rice compared with the $\mathrm{Cd}$ treatment alone. Pretreatment with SA alleviated the Cd-induced inhibition of root growth. The results showed that pretreatment with SA enhanced the antioxidant defense activities in Cd-stressed rice, thus alleviating Cd-induced oxidative damage and enhancing $\mathrm{Cd}$ tolerance. The possible mechanism of SA-induced $\mathrm{H}_{2} \mathrm{O}_{2}$ signaling in mediating Cd tolerance was discussed.
\end{abstract}

(C) 2006 Elsevier Ltd. All rights reserved.

Keywords: Antioxidant system; Cadmium; Hydrogen peroxide; Rice; Salicylic acid

\section{Introduction}

Cadmium (Cd) is widespread in the environment and is highly toxic to living organisms. In plants, Cd interferes with many cellular processes mainly by formation of

\footnotetext{
* Corresponding authors. Present address: Institute of Soil and Fertilizer, Ministry of Agriculture Key Laboratory of Plant Nutrition and Nutrient Cycling, Chinese Academy of Agricultural Sciences, Beijing 100081, PR China. Tel.: +86106891 8657; fax: +861068975161.

E-mail addresses: ycliang@caas.ac.cn (Y.C. Liang),ygzhu@mail.rcees.ac. cn (Y.G. Zhu).
}

complexes with functional proteins, displacement of essential metal ions from the plasma membrane, and the alteration of antioxidant system hence accumulating reactive oxygen species (ROS) and resulting in "oxidative stress" (see review by Schützendübel and Polle, 2002).

Accumulation of ROS, including $\mathrm{H}_{2} \mathrm{O}_{2}$, causes oxidative damage in plants because they oxidize organic compounds and induce membrane lipid peroxidation in the cellular environment (Schützendübel and Polle, 2002). Due to their highly reactive nature, ROS are kept as low as possible in plants by an efficient ROS-scavenging system, including enzymatic antioxidants (e.g. superoxide dismutase, catalase, and peroxidase) 
and non-enzymatic metabolites (e.g. glutathione, ascorbic acid) (Dat et al., 2000; Mittler et al., 2004; Foyer and Noctor, 2005). Recently, ROS, particularly $\mathrm{H}_{2} \mathrm{O}_{2}$, have been proposed as essential signals in both biotic and abiotic stress responses (Dat et al., 2000; Mittler et al., 2004; Foyer and Noctor, 2005). The homeostasis of ROS is required to control the subtle to balance between the important signaling roles in plant defense and the damaging effects of excessive ROS (Mittler et al., 2004; Foyer and Noctor, 2005). This is regulated by highly complex gene networks and signaling pathways (Mittler et al., 2004).

Salicylic acid (SA) has been proposed as an endogenous signal associated with regulating oxidant levels in response to biotic stress. Upon pathogen attack, SA accumulates to high levels at the site of pathogenic infection, binds and inhibits tobacco CAT activity both in vitro and in vivo, thereby leading to an increase in the endogenous level of $\mathrm{H}_{2} \mathrm{O}_{2}$, which could then serve as a secondary messenger to induce the expression of pathogenesis-related proteins and initiate the development of systemic acquired resistance (Chen et al., 1993). Recent studies have shown that SA also plays an important role in provoking plant resistance to various abiotic stresses. For example, treating mustard (Sinapis alba L.) seedlings with exogenous SA improved their thermo-tolerance and heat acclimation, especially in young leaves (Dat et al., 1998). Spraying banana (Musa acuminata coll., cv.) seedlings with SA (Kang et al., 2003) and exposing seedling of maize (Zea mays L.), rice (Oryza sativa L.) and cucumber (Cucumis sati$v u s$ L.) to SA significantly strengthened a tolerance to the subsequent chilling stress (Kang and Saltveit, 2002). SA is also involved in plants subject to salt (Borsani et al., 2001) and heavy metal stresses (Metwally et al., 2003; Yang et al., 2003; Drazic and Mihailovic, 2005).

Since the mode of SA signaling pathway is associated with increased $\mathrm{H}_{2} \mathrm{O}_{2}$ levels (Chen et al., 1993), it might be expected that SA pretreatment would accentuate the oxidative stress caused by Cd toxicity. However, several studies have shown that pretreatment of SA enhanced the resistance of plants to Cd-induced toxicity (Drazic and Mihailovic, 2005), including oxidative damage (Metwally et al., 2003). Metwally et al. (2003) concluded that SA alleviated Cd toxicity to barley roots not at the level of antioxidant defense but by affecting other mechanisms of Cd detoxification. $\mathrm{H}_{2} \mathrm{O}_{2}$ has been considered as an essential signal involved in plant defense against abiotic stress (Dat et al., 2000; Mittler et al., 2004; Foyer and Noctor, 2005). It is hypothesized that the increased $\mathrm{H}_{2} \mathrm{O}_{2}$ induced by SA may act as an important secondary messenger to improve plant defense against the subsequent $\mathrm{Cd}$ stress. Hence, this study focused on the effects of pretreatment of exogenous SA on time-dependent changes in the activities of SOD, POD, CAT, and the concentrations of AsA, GSH and $\mathrm{H}_{2} \mathrm{O}_{2}$, and non-protein thiols (NPT) and lipid peroxidation in rice roots exposed to $\mathrm{Cd}$. This study therefore aimed to explore the mechanisms of (1) the positive effect of SA on Cd tolerance through the regulation of the antioxidant system; and (2) the possible mechanisms of SA-induced $\mathrm{H}_{2} \mathrm{O}_{2}$ signaling pathways in mediating $\mathrm{Cd}$ tolerance in rice roots.

\section{Materials and methods}

\subsection{Plant material and experimental design}

Seeds of rice (O. sativa cv Jiahua 1) were surface sterilized with $\mathrm{H}_{2} \mathrm{O}_{2}$ $(10 \%)$ for $10 \mathrm{~min}$, rinsed thoroughly with distilled water, and sown in trays. When the second leaf emerged, seedlings of uniform size were transferred to hydroponics pots $(1 \mathrm{~L}, \mathrm{PVC}$, six plants per pot) in a growth chamber Each pot contained $1 \mathrm{~L}$ of the kimura $\mathrm{B}$ nutrient solution (full strength composition: $0.37 \mathrm{mM}\left(\mathrm{NH}_{4}\right)_{2} \mathrm{SO}_{4}, 0.55 \mathrm{mM} \mathrm{MgSO}{ }_{4}, 0.18 \mathrm{mM} \mathrm{KNO} 3,0.18 \mathrm{mM}$ $\mathrm{KH}_{2} \mathrm{PO}_{4}, 0.37 \mathrm{mM} \mathrm{Ca}\left(\mathrm{NO}_{3}\right)_{2}, 0.09 \mathrm{mM} \mathrm{K}_{2} \mathrm{SO}_{4}, 50 \mu \mathrm{M}$ Fe(II)-EDTA, $1 \mu \mathrm{M}$ $\mathrm{ZnSO}_{4}, 1 \mu \mathrm{M} \mathrm{CuSO}_{4}, 5 \mu \mathrm{M} \mathrm{MnSO}_{4}, 10 \mu \mathrm{M} \mathrm{H} \mathrm{H}_{3} \mathrm{BO}_{4}, 0.5 \mu \mathrm{M} \mathrm{Na} \mathrm{NoO}_{4}$, $100 \mu \mathrm{M} \mathrm{NaCl}, 0.2 \mu \mathrm{M} \mathrm{CoSO}$. The nutrient solution was renewed twice a week. The pots were randomly arranged daily during the growth period. Daily photoperiod was $14 \mathrm{~h}$ (8:00-22:00) with controlled temperature $\left(25^{\circ} \mathrm{C} / 18{ }^{\circ} \mathrm{C}\right.$, day/night), $70 \%$ relative humidity all day, and photosynthetic photon flux density (PPFD) in the range of $350 \mu \mathrm{mol} \mathrm{m}^{-2} \mathrm{~s}^{-1}$.

Forty-five days after germination (17 days for emergence of second leaf and 28 days for acclimation of hydroponic condition and growth), uniform individuals were selected for the experiments. After preliminary experiments on the effects of a range of concentration of $\mathrm{Cd}$ and $\mathrm{SA}$ on root growth had been performed, the following four treatments with four replicates each were established, including control (neither addition of $\mathrm{Cd}$ nor SA), $50 \mu \mathrm{M} \mathrm{Cd}\left(\mathrm{CdCl}_{2}\right)$, pretreatment of $10 \mu \mathrm{M} \mathrm{SA}$ alone and pretreatment of $10 \mu \mathrm{M}$ SA followed by $50 \mu \mathrm{M} \mathrm{Cd}$. Rice roots were exposed to $10 \mu \mathrm{M} \mathrm{SA}$ in nutrient solution for $24 \mathrm{~h}$ before $\mathrm{Cd}$ treatment. Then, roots from four replicates per treatment were harvested on 2, 4 and 6 days after $\mathrm{Cd}$ treatment, and stored at $-80^{\circ} \mathrm{C}$ immediately after fresh weight determination. The nutrient solution was renewed immediately after sampling. Three independent experiments were performed, one to study root antioxidant enzyme activities, one to determine non-enzymatic antioxidants, and the other to measure root growth (fresh weight) and concentrations of $\mathrm{H}_{2} \mathrm{O}_{2}$ and MDA. Each experiment was duplicated to ensure that the data obtained were reliable.

\subsection{Assays of enzymatic antioxidants in rice roots}

Fresh root samples $(0.5 \mathrm{~g})$ were ground in lipid $\mathrm{N}_{2}$ using a mortar and pestle and the ground samples were homogenized on ice bath in $10 \mathrm{~mL}$ homogenizing solution containing $50 \mathrm{mM}$ potassium phosphate buffer and $1 \%$ (w/v) polyvinylpyrrolidone ( $\mathrm{pH} 7.8$ ), and extracted at $4{ }^{\circ} \mathrm{C}$. The homogenate was centrifuged at $8000 \times g$ at $4{ }^{\circ} \mathrm{C}$ for $15 \mathrm{~min}$. The supernatant was stored at $4{ }^{\circ} \mathrm{C}$ for analysis of the SOD, CAT and POD activities and soluble protein concentration.

The SOD activity was measured by the photochemical method described by Giannopolitis and Ries (1977). The reaction mixture $(3.0 \mathrm{~mL})$ consisted of $2.95 \mathrm{~mL} 50 \mathrm{mM}$ phosphate buffer (pH 7.8), $13 \mathrm{mM}$ methionine, $75 \mathrm{mM}$ nitroblue tetrazolium, $0.1 \mathrm{mM}$ EDTA, $2 \mathrm{mM}$ riboflavin and $0.05 \mathrm{~mL}$ of enzyme extract. The reaction mixture, which was not exposed to light, did not develop color and served as control. One unit SOD activity was defined as the amount of enzyme required for a $50 \%$ inhibition of the rate of NBT ( $\rho$-nitro blue tetrazolium chloride) reduction measured at $560 \mathrm{~nm}$.

The POD activity was assayed following the method of Beffa et al. (1990). Briefly, the assay mixture contained $2.95 \mathrm{~mL} 100 \mathrm{mM} \mathrm{NaH} \mathrm{PO}_{4}-\mathrm{Na}_{2} \mathrm{HPO}_{4}$ buffer ( $\mathrm{pH}$ 6.0), $2 \mathrm{mM} \mathrm{H}_{2} \mathrm{O}_{2}, 9 \mathrm{mM}$ guaiacol and $0.05 \mathrm{~mL}$ enzyme extract in a total volume of $3.0 \mathrm{~mL}$. Changes in the absorbance of the brown guaiacol at $460 \mathrm{~nm}$ in the presence of $\mathrm{H}_{2} \mathrm{O}_{2}$ were recorded for calculating POD activity.

The CAT activity was assayed using the method described by Aebi (1984). The assay mixture in a total volume of $3.0 \mathrm{~mL}$ contained $2.8 \mathrm{~mL} 50 \mathrm{mM}$ $\mathrm{NaH}_{2} \mathrm{PO}_{4}-\mathrm{Na}_{2} \mathrm{HPO}_{4}$ buffer ( $\mathrm{pH} 7.0$ ), $19 \mathrm{mM} \mathrm{H} \mathrm{H}_{2} \mathrm{O}_{2}$ and $0.2 \mathrm{~mL}$ enzyme extract. The activity was assayed by monitoring the decrease in the absorbance at $240 \mathrm{~nm}$ as a consequence of $\mathrm{H}_{2} \mathrm{O}_{2}$ consumption. Activity was expressed as units ( $\mu \mathrm{M}$ of $\mathrm{H}_{2} \mathrm{O}_{2}$ decomposed per minute) per mg of protein.

Soluble protein concentration was measured following the method described by Bradford (1976) using bovine serum albumin as standard. The assay is based on the stable dye-albumin complex, which can be quantified spectrophotometrically at $590 \mathrm{~nm}$. The protein-dye reagent consisted of $0.01 \%(\mathrm{w} / \mathrm{v})$ Coomassie Brilliant Blue G-250, 4.7\% (w/v) ethanol and 8.5\% (w/v) phosphoric acid. 


\subsection{Assays of AsA and GSH concentrations in rice roots}

The concentration of ascorbic acid (AsA) was measured according to Law et al. (1983). Fresh tissues $(0.5 \mathrm{~g})$ were homogenized in $3 \mathrm{~mL} \mathrm{5 \%} \mathrm{TCA} \mathrm{(tri-}$ chloroacetic acid) solution. The assay mixture $(5.0 \mathrm{~mL})$ contained $1.0 \mathrm{~mL}$ $5 \%$ TCA, $1.0 \mathrm{~mL} 100 \%$ ethanol, $0.5 \mathrm{~mL} \quad 0.4 \% \quad \mathrm{H}_{3} \mathrm{PO}_{4}$-ethanol, $1.0 \mathrm{~mL}$ $0.5 \%$ phenanthroline-ethanol, $0.5 \mathrm{~mL} 0.03 \% \mathrm{FeCl}_{3}$-ethanol and $1.0 \mathrm{~mL}$ enzyme extract. The assay was based on the reduction of $\mathrm{Fe}^{3+}$ to $\mathrm{Fe}^{2+}$ by AsA; $\mathrm{Fe}^{2+}$ was quantified spectrophotometrically at $534 \mathrm{~nm}$ for $90 \mathrm{~min}$ at $30^{\circ} \mathrm{C}$.

Glutathione (GSH) was quantified fluorimetrically according to Hissin and Hilf (1976). Fresh roots $(0.5 \mathrm{~g})$ were ground in a mixture of $1 \mathrm{~mL}$ of $25 \%$ $\mathrm{H}_{3} \mathrm{PO}_{3}$ and $3 \mathrm{~mL}$ of $0.1 \mathrm{M}$ sodium phosphate-EDTA buffer ( $\mathrm{pH}$ 8.0). The homogenate was centrifuged at $10,000 \times g$ for $20 \mathrm{~min}$, and the supernatant was further diluted five folds with sodium phosphate-EDTA buffer $(\mathrm{pH}$ 8.0). The final assay mixture $(2.0 \mathrm{~mL})$ contained $100 \mu \mathrm{L}$ of the diluted supernatant, $1.8 \mathrm{~mL}$ of phosphate-EDTA buffer and $100 \mu \mathrm{l}$ of $O$-phthalaldehyde $\left(1 \mathrm{mg} \mathrm{mL}^{-1}\right)$. After thorough mixing and incubation at room temperature for $15 \mathrm{~min}$, the solution was transferred to a quartz cuvette and the fluorescence at $420 \mathrm{~nm}$ was measured after excitation at $350 \mathrm{~nm}$.

\subsection{Concentration of NPT in rice roots}

The concentration of non-protein thiols (NPT) was determined by measuring the absorbance at $412 \mathrm{~nm}$ following the method of Metwally et al. (2003). For this, fresh segments weighing $0.5 \mathrm{~g}$ were homogenized in an ice bath in $5 \mathrm{~mL}$ of potassium phosphate buffer $(\mathrm{pH} 8.0)$, and the homogenate was centrifuged at $10,000 \times g$ for $20 \mathrm{~min}$. The supernatant was used for NPT assay using 5,5-dithio-2,2-dinitrobenzoic acid as a reagent.

\subsection{Concentration of MDA in rice roots}

The TBA (thiobarbituric acid) test was used to measure lipid peroxidation in roots. The method determines the concentration of MDA (malondialdehyde) as an end product of lipid peroxidation. For this, fresh tissues $(0.5 \mathrm{~g})$ were homogenized in $3 \mathrm{~mL} \mathrm{10 \%} \mathrm{TCA} \mathrm{(trichloroacetic} \mathrm{acid)} \mathrm{solution.} \mathrm{The} \mathrm{homogenate}$ was centrifuged at $2500 \times \mathrm{g}$ for $10 \mathrm{~min}$ and the supernatant was assayed for MDA concentration using an extinction coefficient of $155 \mathrm{mM}^{-1} \mathrm{~cm}^{-1}$ and expressed as $\mathrm{nmol} \mathrm{g}^{-1}$ fresh weight, following the method of Heath and Packer (1968).

\subsection{Concentration of $\mathrm{H}_{2} \mathrm{O}_{2}$ in rice roots}

The concentration of $\mathrm{H}_{2} \mathrm{O}_{2}$ was determined according to Mukherjee and Choudhuri (1983). Briefly, $1.0 \mathrm{~g}$ of fresh segments was homogenized in refrigerated acetone $(10 \mathrm{~mL})$ and was centrifuged at $10,000 \times g$ for $10 \mathrm{~min}$. One milliliter of the supernatant was mixed with $0.1 \mathrm{~mL} 5 \% \mathrm{Ti}\left(\mathrm{SO}_{4}\right)_{2}$ and $0.2 \mathrm{~mL} 19 \%$ ammonia. After the precipitate was formed, the reaction mixture was centrifuged at $10,000 \times g$ for $10 \mathrm{~min}$. The resulting pellet was dissolved in $2 \mathrm{M}$ $\mathrm{H}_{2} \mathrm{SO}_{4}$ and the absorbance was read at $415 \mathrm{~nm}$. The $\mathrm{H}_{2} \mathrm{O}_{2}$ level was calculated according to a standard curve of $\mathrm{H}_{2} \mathrm{O}_{2}$.

\subsection{Statistical analysis}

All data in the tables were subject to analysis of variance and expressed as means \pm standard errors of four replicates. Statistical significance of the means was compared by Duncan's New Multiple Range Test at the 5\% probability level using SPSS software.

\section{Results}

Fresh weight of plants in the control treatment increased with time ( $r=0.9995, n=3, P<0.01)$, whereas Cd exposure did not increase plant growth linearly with time during the experimental period $(r=0.7206, n=3, P>0.05)($ Table 1$)$.
Table 1

Fresh weight (means \pm S.E. expressed in $\mathrm{g}, n=4$ ) of rice roots treated with $50 \mu \mathrm{M} \mathrm{Cd}$ or pretreated with $10 \mu \mathrm{M} \mathrm{SA}$

\begin{tabular}{llll}
\hline Day (d) after treatment & 2 & 4 & 6 \\
\hline Treatment & & & \\
$\quad$ Control & $1.59 \pm 0.12 \mathrm{a}$ & $1.85 \pm 0.12 \mathrm{a}$ & $2.14 \pm 0.15 \mathrm{a}$ \\
$50 \mu \mathrm{M} \mathrm{Cd}$ & $1.54 \pm 0.08 \mathrm{a}$ & $1.62 \pm 0.17 \mathrm{a}$ & $1.60 \pm 0.10 \mathrm{c}$ \\
$10 \mu \mathrm{M} \mathrm{SA}$ & $1.57 \pm 0.08 \mathrm{a}$ & $1.86 \pm 0.17 \mathrm{a}$ & $2.11 \pm 0.22 \mathrm{a}$ \\
$10 \mu \mathrm{M} \mathrm{SA}+50 \mu \mathrm{M} \mathrm{Cd}$ & $1.51 \pm 0.05 \mathrm{a}$ & $1.69 \pm 0.03 \mathrm{a}$ & $1.85 \pm 0.06 \mathrm{~b}$ \\
\hline
\end{tabular}

Means followed by different letters within the same column are significantly different at $P<0.05$ according to Duncan's New Multiple Range Test at the $5 \%$ probability level.

Pretreatment with SA did not affect the root growth compared with the control. However, pretreatment with SA significantly mitigated the growth inhibition by $\mathrm{Cd}$ stress on day 6 (by $16 \%$ ) compared with $\mathrm{Cd}$ treatment alone.

Addition of $\mathrm{Cd}$ significantly increased $\mathrm{H}_{2} \mathrm{O}_{2}$ concentration in rice roots, by 2-, 3- and 3.5-fold compared with control on days 2, 4 and 6, respectively (Table 2). SA pretreatment alone also significantly increased $\mathrm{H}_{2} \mathrm{O}_{2}$ concentrations throughout the experimental period, but the effect (42-100\% increase) was smaller than that of $\mathrm{Cd}$ stress (Table 2). Under Cd stress, SA pretreatment decreased $\mathrm{H}_{2} \mathrm{O}_{2}$ concentrations progressively throughout the 6-day experimental period, and the significant difference was observed on day 6 .

Table 3 shows the effects of SA pretreatment and Cd exposure on the concentration of MDA in rice roots. MDA levels in Cd-stressed plants were significantly higher than control throughout the experimental period. SA pretreatment significantly reduced MDA concentrations on days 4 and 6 compared with $\mathrm{Cd}$ treatment alone (Table 3 ). There was no significant difference in MDA between the SA pretreatment and control throughout the experimental period (Table 3).

Addition of Cd significantly decreased SOD activity in rice roots on day 2 compared with control (Table 4 ), followed by a gradual decrease with increasing $\mathrm{Cd}$ exposure time. Under Cd stress, SA pretreatment significantly increased SOD activity compared with corresponding $\mathrm{Cd}$ alone treatment (by $15.3 \%$ on day $2,20 \%$ on day 4 , and $23 \%$ on day 6 , respectively, Table 4). SA pretreatment alone did not affect SOD activity.

POD activity in rice roots was significantly decreased by Cd stress compared with control throughout the experimental period (Table 5). Pretreatment with SA in Cd-stressed roots

Table 2

$\mathrm{H}_{2} \mathrm{O}_{2}$ concentration (means \pm S.E. expressed in $\mathrm{nmol} \mathrm{g}^{-1} \mathrm{FW}, n=4$ ) in rice roots treated with $50 \mu \mathrm{M} \mathrm{Cd}$ or pretreated with $10 \mu \mathrm{M} \mathrm{SA}$

\begin{tabular}{llll}
\hline Day $(\mathrm{d})$ after treatment & 2 & 4 & 6 \\
\hline Treatment & & & \\
Control & $223 \pm 39 \mathrm{c}$ & $201 \pm 46 \mathrm{c}$ & $234 \pm 30 \mathrm{~d}$ \\
$50 \mu \mathrm{M} \mathrm{Cd}$ & $461 \pm 32 \mathrm{a}$ & $601 \pm 121 \mathrm{a}$ & $819 \pm 55 \mathrm{a}$ \\
$10 \mu \mathrm{M} \mathrm{SA}$ & $322 \pm 32 \mathrm{~b}$ & $402 \pm 57 \mathrm{~b}$ & $333 \pm 43 \mathrm{c}$ \\
$10 \mu \mathrm{M} \mathrm{SA}+50 \mu \mathrm{M} \mathrm{Cd}$ & $413 \pm 54 \mathrm{a}$ & $505 \pm 45 \mathrm{ab}$ & $684 \pm 43 \mathrm{~b}$ \\
\hline
\end{tabular}

Means followed by different letters within the same column are significantly different at $P<0.05$ according to Duncan's New Multiple Range Test at the $5 \%$ probability level. 
Table 3

MDA concentration (means \pm S.E. expressed in $\mathrm{nmol} \mathrm{g}^{-1} \mathrm{FW}, n=4$ ) in rice roots treated with $50 \mu \mathrm{M}$ Cd or pretreated with $10 \mu \mathrm{M} \mathrm{SA}$

\begin{tabular}{llll}
\hline Day $(\mathrm{d})$ after treatment & 2 & 4 & 6 \\
\hline Treatment & & & \\
$\quad$ Control & $29.8 \pm 6.4 \mathrm{c}$ & $34.4 \pm 4.5 \mathrm{~b}$ & $27.5 \pm 2.7 \mathrm{c}$ \\
$50 \mu \mathrm{M} \mathrm{Cd}$ & $44.5 \pm 5.1 \mathrm{a}$ & $48.2 \pm 7.6 \mathrm{a}$ & $46.9 \pm 0.7 \mathrm{a}$ \\
$10 \mu \mathrm{M} \mathrm{SA}$ & $34.9 \pm 4.9 \mathrm{bc}$ & $39.0 \pm 3.4 \mathrm{~b}$ & $31.0 \pm 2.4 \mathrm{c}$ \\
$10 \mu \mathrm{M} \mathrm{SA}+50 \mu \mathrm{M} \mathrm{Cd}$ & $43.2 \pm 6.4 \mathrm{ab}$ & $35.8 \pm 4.0 \mathrm{~b}$ & $38.1 \pm 4.9 \mathrm{~b}$ \\
\hline
\end{tabular}

Means followed by different letters within the same column are significantly different at $P<0.05$ according to Duncan's New Multiple Range Test at the $5 \%$ probability level.

significantly alleviated the reduction in POD activity on day 2, but this effect diminished on days 4 and 6. Pretreatment of SA alone did not alter POD activity significantly compared with control (Table 5).

Exposure of $\mathrm{Cd}$ decreased CAT activity in rice roots by approximately $50 \%$ throughout the 6-day experimental period compared with control (Table 6). SA pretreatment alone also decreased CAT activity, and the effect was similar to Cd treatment alone. However, SA pretreatment significantly increased CAT activities in Cd-stressed rice roots compared with that of Cd alone treatment throughout the whole experiment (Table 6).

Effects of $\mathrm{Cd}$ and SA on levels of GSH and NPT in rice roots are shown in Table 7 . Cd exposure significantly increased the concentration of GSH, by $151 \%$ on day 4 and $120 \%$ on day 6 compared with control (Table 7). The largest response in the GSH concentration occurred in SA pretreatment followed by $\mathrm{Cd}$ exposure; the GSH concentration increased by 2.2-3.6-fold compared with the control.

There were no significant differences in non-protein thiols' (NPT) concentrations among Cd treatment, SA pretreatment and control on day 2 (Table 7). SA pretreatment and $\mathrm{Cd}$ alone treatment significantly increased NPT concentration compared with control on days 4 and 6. Cd stress with SA pretreatment produced a larger effect on NPT concentration than $\mathrm{Cd}$ alone treatment.

On day 2, Cd stress induced an increase in the AsA concentrations in rice roots (Table 8). AsA concentrations were increased by $161 \%$ in $\mathrm{Cd}$ alone treatment, and $145 \%$ in $\mathrm{SA}$ pretreatment under $\mathrm{Cd}$ stress on day 4 , respectively. Significant differences were observed on day 6 among the four treatments. For example, AsA concentrations increased by $82 \%$ in $\mathrm{Cd}$ alone

Table 4

Effect of SA on SOD activity (means \pm S.E. expressed in $\mathrm{U} \mathrm{mg}^{-1}$ protein, $n=4)$ in rice roots with $50 \mu \mathrm{M} \mathrm{Cd}$ or pretreated with $10 \mu \mathrm{M} \mathrm{SA}$

\begin{tabular}{lrrr}
\hline Day $(\mathrm{d})$ after treatment & \multicolumn{1}{c}{4} & 6 \\
\hline Treatment & & & \\
Control & $104 \pm 8 \mathrm{a}$ & $107 \pm 9 \mathrm{a}$ & $116 \pm 3 \mathrm{a}$ \\
$50 \mu \mathrm{M} \mathrm{Cd}$ & $85 \pm 7 \mathrm{~b}$ & $70 \pm 9 \mathrm{c}$ & $65 \pm 5 \mathrm{c}$ \\
$10 \mu \mathrm{M} \mathrm{SA}$ & $98 \pm 6 \mathrm{a}$ & $118 \pm 3 \mathrm{a}$ & $103 \pm 10 \mathrm{a}$ \\
$10 \mu \mathrm{M} \mathrm{SA}+50 \mu \mathrm{M} \mathrm{Cd}$ & $93 \pm 7 \mathrm{a}$ & $84 \pm 11 \mathrm{~b}$ & $80 \pm 9 \mathrm{~b}$ \\
\hline
\end{tabular}

Means followed by different letters within the same column are significantly different at $P<0.05$ according to Duncan's New Multiple Range Test at the $5 \%$ probability level.
Table 5

Effect of SA on POD activity (means \pm S.E. expressed in $\mathrm{U} \mathrm{mg}^{-1}$ protein, $n=4)$ in rice roots treated with $50 \mu \mathrm{M}$ Cd or pretreated with $10 \mu \mathrm{M} \mathrm{SA}$

\begin{tabular}{lrll}
\hline Day (d) after treatment & \multicolumn{1}{l}{4} & \multicolumn{1}{l}{6} \\
\hline Treatment & & & \\
Control & $9.3 \pm 1.5 \mathrm{a}$ & $7.4 \pm 0.3 \mathrm{a}$ & $8.9 \pm 0.5 \mathrm{a}$ \\
$50 \mu \mathrm{M} \mathrm{Cd}$ & $6.9 \pm 0.6 \mathrm{~b}$ & $4.6 \pm 0.4 \mathrm{~b}$ & $4.1 \pm 0.7 \mathrm{~b}$ \\
$10 \mu \mathrm{M} \mathrm{SA}$ & $10.5 \pm 0.3 \mathrm{a}$ & $7.1 \pm 0.5 \mathrm{a}$ & $7.0 \pm 1.7 \mathrm{a}$ \\
$10 \mu \mathrm{M} \mathrm{SA}+50 \mu \mathrm{M} \mathrm{Cd}$ & $10.2 \pm 2.2 \mathrm{a}$ & $5.0 \pm 0.8 \mathrm{~b}$ & $4.1 \pm 0.1 \mathrm{~b}$ \\
\hline
\end{tabular}

Means followed by different letters within the same column are significantly different at $P<0.05$ according to Duncan's New Multiple Range Test at the $5 \%$ probability level.

treatment, $169 \%$ in SA pretreatment and $229 \%$ in SA pretreatment under Cd stress, respectively, compared with control.

\section{Discussion}

\subsection{Inhibition of antioxidant enzymes: a possible cause of the Cd-induced oxidative stress}

$\mathrm{Cd}$ is known to induce oxidative damage to higher plants (Schützendübel and Polle, 2002). In the present study, progressive enhancement of $\mathrm{H}_{2} \mathrm{O}_{2}$ and MDA concentrations in rice roots with increasing $\mathrm{Cd}$ exposure time (Tables 2 and 3 ) showed that the oxidative stress and the peroxidation of membrane lipids were induced by $\mathrm{Cd}$ treatment. Activities of the major antioxidant enzymes (SOD, CAT and POD) in rice roots were significantly decreased by $\mathrm{Cd}$ stress during the experimental period (Tables 4-6). Generally, a decrease in SOD activity results in a decrease in $\mathrm{H}_{2} \mathrm{O}_{2}$ levels, since SOD detoxifies superoxide anion free radicals accompanying the formation of $\mathrm{H}_{2} \mathrm{O}_{2}$. However, the levels of ROS and the extent of oxidative damage depend largely upon the whole antioxidant defense system and the co-operation or coordination among the ROS-scavenging enzymes (Liang et al., 2003). It was also reported that SOD activity was decreased along with enhancement of $\mathrm{H}_{2} \mathrm{O}_{2}$ levels in Arabidopsis thaliana exposed to 300 or $500 \mu \mathrm{M} \mathrm{Cd}$ for a longer time (21 days) and such accumulation of the $\mathrm{H}_{2} \mathrm{O}_{2}$ might rather be a result of lowered activity of CAT responsible for scavenging $\mathrm{H}_{2} \mathrm{O}_{2}$ (Cho and Seo, 2005). This decreased CAT activity along with the decreased SOD activity might contribute to Cd-induced phytotoxicity (Cho and Seo, 2005). Similar results were reported in Populus $\times$ canescens roots exposed to $50 \mu \mathrm{M} \mathrm{Cd}$ for $50 \mathrm{~h}$

Table 6

Effect of SA on CAT activity (means \pm S.E. expressed in $\mathrm{Umg}^{-1}$ protein $\left.\min ^{-1}, n=4\right)$ in rice roots treated with $50 \mu \mathrm{M} \mathrm{Cd}$ or pretreated with $10 \mu \mathrm{M} \mathrm{SA}$

\begin{tabular}{lrrr}
\hline Day $(\mathrm{d})$ after treatment & \multicolumn{1}{c}{4} & \multicolumn{1}{c}{6} \\
\hline Treatment & & & \\
Control & $20 \pm 4 \mathrm{a}$ & $17 \pm 2 \mathrm{a}$ & $20 \pm 5 \mathrm{a}$ \\
$50 \mu \mathrm{M} \mathrm{Cd}$ & $9 \pm 1 \mathrm{~b}$ & $9 \pm 3 \mathrm{~b}$ & $11 \pm 2 \mathrm{~b}$ \\
$10 \mu \mathrm{M} \mathrm{SA}$ & $11 \pm 5 \mathrm{~b}$ & $8 \pm 1 \mathrm{~b}$ & $7 \pm 1 \mathrm{~b}$ \\
$10 \mu \mathrm{M} \mathrm{SA}+50 \mu \mathrm{M} \mathrm{Cd}$ & $20 \pm 4 \mathrm{a}$ & $21 \pm 4 \mathrm{a}$ & $21 \pm 3 \mathrm{a}$ \\
\hline
\end{tabular}

Means followed by different letters within the same column are significantly different at $P<0.05$ according to Duncan's New Multiple Range Test at the $5 \%$ probability level. 
Table 7

GSH and NPT concentrations (means \pm S.E. expressed in $\mathrm{ng} \mathrm{g}^{-1} \mathrm{FW}, n=4$ ) in rice roots treated with $50 \mu \mathrm{M} \mathrm{Cd}$ or pretreated with $10 \mu \mathrm{M} \mathrm{SA}$

\begin{tabular}{lrrr}
\hline Day (d) after treatment & \multicolumn{1}{c}{4} & \multicolumn{1}{c}{6} \\
\hline Treatment & & & \\
$\quad$ GSH & & & \\
Control & $6.1 \pm 1.2 \mathrm{c}$ & $5.7 \pm 1.3 \mathrm{c}$ & $6.0 \pm 1.4 \mathrm{c}$ \\
$50 \mu \mathrm{M} \mathrm{Cd}$ & $9.1 \pm 1.9 \mathrm{~b}$ & $14.3 \pm 2.3 \mathrm{~b}$ & $12.9 \pm 1.5 \mathrm{~b}$ \\
$10 \mu \mathrm{M} \mathrm{SA}$ & $7.6 \pm 1.3 \mathrm{bc}$ & $5.7 \pm 0.6 \mathrm{c}$ & $7.8 \pm 0.7 \mathrm{c}$ \\
$10 \mu \mathrm{M} \mathrm{SA}+50 \mu \mathrm{M} \mathrm{Cd}$ & $13.2 \pm 1.5 \mathrm{a}$ & $19.4 \pm 2.3 \mathrm{a}$ & $21.8 \pm 1.6 \mathrm{a}$ \\
$\mathrm{NPT}$ & & & \\
Control & $55 \pm 6 \mathrm{~b}$ & $55 \pm 5 \mathrm{c}$ & $54 \pm 9 \mathrm{c}$ \\
$50 \mu \mathrm{M} \mathrm{Cd}$ & $62 \pm 3 \mathrm{~b}$ & $70 \pm 6 \mathrm{~b}$ & $74 \pm 3 \mathrm{~b}$ \\
$10 \mu \mathrm{M} \mathrm{SA}$ & $53 \pm 5 \mathrm{~b}$ & $65 \pm 5 \mathrm{~b}$ & $74 \pm 3 \mathrm{~b}$ \\
$10 \mu \mathrm{M} \mathrm{SA}+50 \mu \mathrm{M} \mathrm{Cd}$ & $76 \pm 8 \mathrm{a}$ & $124 \pm 4 \mathrm{a}$ & $101 \pm 11 \mathrm{a}$ \\
\hline
\end{tabular}

Means followed by different letters within the same column are significantly different at $P<0.05$ according to Duncan's New Multiple Range Test at the $5 \%$ probability level.

(Schützendübel et al., 2002). It seems to suggest that the decrease in capability of scavenging $\mathrm{H}_{2} \mathrm{O}_{2}$ enzymes, such as POD and CAT (Tables 5 and 6) might be the reason for the accumulation of $\mathrm{H}_{2} \mathrm{O}_{2}$ (Table 2).

\subsection{Increased non-enzymatic molecular antioxidants under Cd stress}

Significant increases in GSH, NPT concentrations were observed in Cd-stressed rice roots (Table 7). NPT are mainly phytochelatins (Metwally et al., 2003), which play an essential role in Cd detoxification. Increase in GSH and NPT in plants might be an important defense response to $\mathrm{Cd}$ toxicity, as has been found in Cd-stressed Phragmites australis and Arabidopsis (Lee et al., 2003; Pietrini et al., 2003). Generally, Cd initially depletes GSH in a matter of hours because of an enhanced demand of GSH for Cd detoxification (Schützendübel et al., 2001). Upon prolonged exposure, GSH level tends to recover, or even exceed the control level (Schützendübel et al., 2001). In the present study, 2-day-Cd-exposure was probably too long to detect this initial change in GSH.

In the present study, increase in AsA under Cd stress (Table 8 ) concurred with the effect of $\mathrm{Cd}$ treatment on $P$. australis (Iannelli et al., 2002) and pine (Schützendübel et al., 2001). The enhancement of AsA levels might help the plant to cope with the Cd-induced oxidative damage. In wheat, increasing

Table 8

AsA concentration (means \pm S.E. expressed in $\mathrm{mg} \mathrm{g}^{-1} \mathrm{FW}, n=4$ ) in rice roots treated with $50 \mu \mathrm{M}$ Cd or pretreated with $10 \mu \mathrm{M} \mathrm{SA}$

\begin{tabular}{llll}
\hline Day $(\mathrm{d})$ after treatment & 2 & 4 & 6 \\
\hline Treatment & & & \\
$\quad$ Control & $1.39 \pm 0.35 \mathrm{~b}$ & $0.78 \pm 0.23 \mathrm{~b}$ & $1.27 \pm 0.20 \mathrm{~d}$ \\
$50 \mu \mathrm{M} \mathrm{Cd}$ & $1.94 \pm 0.27 \mathrm{a}$ & $2.04 \pm 0.22 \mathrm{a}$ & $2.32 \pm 0.43 \mathrm{c}$ \\
$10 \mu \mathrm{M} \mathrm{SA}$ & $1.46 \pm 0.15 \mathrm{~b}$ & $1.06 \pm 0.16 \mathrm{~b}$ & $3.42 \pm 0.28 \mathrm{~b}$ \\
$10 \mu \mathrm{M} \mathrm{SA}+50 \mu \mathrm{M} \mathrm{Cd}$ & $1.49 \pm 0.08 \mathrm{~b}$ & $1.91 \pm 0.35 \mathrm{a}$ & $4.19 \pm 0.29 \mathrm{a}$ \\
\hline
\end{tabular}

Means followed by different letters within the same column are significantly different at $P<0.05$ according to Duncan's New Multiple Range Test at the $5 \%$ probability level. levels of endogenous AsA induced by L-Galactono-1,4-lactone (GalL) increased Cd tolerance (Zhao et al., 2005). Accumulation of AsA under Cd stress might be due to the enhancement of monodehydroascorbate reductase (MDHAR) activity hence accelerating AsA cycling (Schützendübel et al., 2001).

Clearly, the oxidative response of plants to $\mathrm{Cd}$ stress is complex with the extent of oxidative stress being dependent upon the whole antioxidant defense system. Cd stress initially depletes GSH and inhibits CAT, APX (Schützendübel et al., 2001), and glutathione reductase (GR). This causes an accumulation of $\mathrm{H}_{2} \mathrm{O}_{2}$ acting as a signaling molecule in the activation of cellular defenses including CAT and APX (Prasad et al., 1994) and induces the synthesis of ASA and GSH (Schützendübel et al., 2001), which involves APX, GR and MDHAR/DHAR. Unfortunately, the activity of APX, GR and MDHAR/DHAR was not monitored in the present study considering the extent of analysis. Thus, further studies are needed aiming at examining the whole picture of the antioxidant defense system including antioxidant enzymes and nonenzymatic antioxidants in response to $\mathrm{Cd}$ exposure.

\subsection{SA-elevated enzymatic and non-enzymatic antioxidants contributed to alleviation of Cd toxicity in rice roots}

In the present study, pretreatment with SA significantly alleviated growth inhibition by $\mathrm{Cd}$ stress (Table 1) and also mitigated declines in activities of antioxidant enzymes (SOD, CAT and POD), and further increased levels of GSH, NPT and AsA in $\mathrm{Cd}$-stressed rice roots (Tables 4-8). The increase in GSH might be ascribed to SA-activation of serine acetyltransferase (SAT), an enzyme closely related to the synthesis of GSH (Freeman et al., 2005). Elevated AsA levels might be due to SA-enhanced activities of dehydroascorbate reductase (DHAR) and MDHAR (Dat et al., 1998). As a result, SA pretreatment increased $\mathrm{Cd}$ tolerance by alleviation of growth inhibition (Table 1) and of Cd-induced oxidative stress as evidenced by the decrease in MDA concentrations (Table 3 ). The results presented here are in disagreement with the report by Metwally et al. (2003), who showed that the SA effect on alleviating $\mathrm{Cd}$ toxicity in barley seedlings was not related to the antioxidant defense system since SA treatment strongly or completely suppressed the Cd-induced up-regulation of the antioxidant enzyme activities. This discrepancy might be caused by the different research methods and plant species used. In the experiment with barley (Metwally et al., 2003), seeds were soaked for $6 \mathrm{~h}$ in $0.5 \mathrm{mM} \mathrm{SA}$, whereas in the present study, rice seedlings were exposed to $10 \mu \mathrm{M} \mathrm{SA}$ for $24 \mathrm{~h}$ before Cd treatment (see Section 2).

\subsection{Possible signaling role of $\mathrm{SA}$ and $\mathrm{SA}$-induced $\mathrm{H}_{2} \mathrm{O}_{2}$ in plant defense against $C d$-induced oxidative stress}

SA is an important signal molecule in plant defense. The mode of SA was proposed to be inhibition of CAT activity and increase in $\mathrm{H}_{2} \mathrm{O}_{2}$ level during plant-pathogen interactions (Chen et al., 1993). In the present study, pretreatment with SA 
alone specifically inhibited CAT activity (Table 6) and increased $\mathrm{H}_{2} \mathrm{O}_{2}$ level (Table 2) in rice roots. $\mathrm{H}_{2} \mathrm{O}_{2}$ accumulation affected by SA has also been observed in other plant species (Chen et al., 1993; Chen et al., 1997; Rao et al., 1997). It has been proposed that SA acts as a one-electron donor that siphons the extremely fast CAT cycle into the relatively slow peroxidative cycle $(\sim 1000$ times slower)(Durner and Klessig, 1996). Besides inhibition of CAT, SA-blocked electron flow from the substrate dehydrogenises to the ubiquinone pool in mitochondria might also be an important mechanism of triggering $\mathrm{H}_{2} \mathrm{O}_{2}$ generation (Norman et al., 2004).

Interestingly, recent data show that $\mathrm{H}_{2} \mathrm{O}_{2}$ acts as an essential messenger inducing gene expression in response to environmental stresses (Dat et al., 2000; Mittler et al., 2004; Foyer and Noctor, 2005). In the process of programmed cell death, the specific induction of the genes coding for glutathione S-transferase (GST) and glutathione peroxidases (GPX) in soybean confirmed the signaling properties of $\mathrm{H}_{2} \mathrm{O}_{2}$ in plants (Levine et al., 1994). Generally, sensing $\mathrm{H}_{2} \mathrm{O}_{2}$ signaling in plant is mediated by the antioxidant buffers, such as NPT (including GSH) and AsA (Foyer and Noctor, 2005), and the latter in turn plays a key role in defense against various environmental stresses (Foyer and Noctor, 2005). For example, GSH biosynthesis is directly linked to stress defense gene expression in Arabidopsis, such as APX2 (Ball et al., 2004). The $v t c l$, an AsA resistant Arabidopsis mutant, is very sensitive to various abiotic stresses (e.g. ozone, freezing and UV-B irradiation), which suggests that low AsA decreased the threshold for sensing stress (Conklin et al., 1996). Thus, in the present study, SA-induced $\mathrm{H}_{2} \mathrm{O}_{2}$ (Table 2) along with an increase in production of NPT and AsA (Tables 7 and 8) in rice roots might "set up" the rice plant to respond to Cd more effectively. This hypothesis was not only supported by the alleviated growth inhibition (Table 1) and decreased $\mathrm{H}_{2} \mathrm{O}_{2}$ and MDA concentrations (Tables 2 and 3 ) in Cd-treated rice plants, but also confirmed by several previous studies on the signaling role of $\mathrm{H}_{2} \mathrm{O}_{2}$ with respect to plant stress acclimation. Maize seedlings injected with $\mathrm{H}_{2} \mathrm{O}_{2}$ and menadione $\left(\mathrm{a}_{2} \mathrm{O}_{2}\right.$-generating compound) became more tolerant against chilling stress (Prasad et al., 1994; Prasad, 1996). Nodal potato explants sub-cultured from $\mathrm{H}_{2} \mathrm{O}_{2}$-treated micro-plants were resistant to heat shock for $15 \mathrm{~h}$ even after 4 weeks of treatment (Lopez-Delgado et al., 1998). Heat shock response can be completely inhibited by removal of $\mathrm{H}_{2} \mathrm{O}_{2}$ because the expression of genes such as those encoding HSF21 and HSF5 and cytosolic APXI is modulated by $\mathrm{H}_{2} \mathrm{O}_{2}$ signals (Davletova et al., 2005).

Taken together, evidence from this study showed that SA enhanced the enzymatic and non-enzymatic antioxidants in rice roots subject to $\mathrm{Cd}$ stress, thus suppressing $\mathrm{Cd}$-induced oxidative damage and enhancing $\mathrm{Cd}$ tolerance. SA not only specifically regulated the CAT activity, but also played roles in enhancing AsA, GSH, and NPT levels in plants subject to $\mathrm{Cd}$ stress. In addition, SA influenced the other signaling pathways in plant defense, such as $\mathrm{H}_{2} \mathrm{O}_{2}$. The current limitation of the complete description of SA signal transduction pathway in plants means that future studies are needed on the dissection of the complex network of SA and its involvement in plant defense against biotic and abiotic stresses using genetic, genomic and biochemical approaches.

\section{Acknowledgments}

The study is jointly supported by the grants from Ministry of Science and Technology of China (2004BA520A13-6), National Foundation for Recruiting Oversea Chinese Students (2005-2007) and National Natural Science Foundation of China (Approved No. 30170536). It is also financed by the Distinguished Talent Program of the Chinese Academy of Agricultural Sciences granted to Y.L. and the International Partnership Program of the Chinese Academy of Sciences.

\section{References}

Aebi, H., 1984. Catalase in vitro. Methods in Enzymology 105, 121-126.

Ball, L., Accotto, G.P., Bechtold, U., Creissen, G., Funck, D., Jimenez, A., Kular, B., Leyland, N., Mejia-Carranza, J., Reynolds, H., Karpinski, S., Mullineaux, P.M., 2004. Evidence for a direct link between glutathione biosynthesis and stress defense gene expression in Arabidopsis. Plant Cell 16, 2448-2462.

Beffa, R., Martin, H.V., Pilet, P.E., 1990. In vitro oxidation of indoleacetic acid by soluble auxin-oxidases and peroxidases from maize root. Plant Physiology 94, 485-491.

Borsani, O., Valpuesta, V., Botella, M.A., 2001. Evidence for a role of salicylic acid in the oxidative damage generated by $\mathrm{NaCl}$ and osmotic stress in Arabidopsis seedlings. Plant Physiology 126, 1024-1030.

Bradford, M.M., 1976. A rapid and sensitive method for the quantitation of microgram quantities of protein utilizing the principle of protein-dye binding. Analytical Biochemistry 72, 248-254.

Chen, Z.X., Silva, H., Klessig, D.F., 1993. Active oxygen species in the induction of plant systematic acquired resistance by salicylic acid. Science 262, 1883-1886.

Chen, Z.X., Lyer, S., Caplan, A., Klessig, D.F., Fan, B.F., 1997. Differential accumulation of salicylic acid and salicylic acid-sensitive catalase in different rice tissues. Plant Physiology 114, 193-201.

Cho, U.H., Seo, N.H., 2005. Oxidative stress in Arabidopsis thaliana exposed to cadmium is due to hydrogen peroxide accumulation. Plant Science 168, 113-120.

Conklin, P.L., Williams, E.H., Last, R.L., 1996. Environmental stress sensitivity of an ascorbic acid-deficient Arabidopsis mutant. Proceedings of the National Academy of Sciences of the United States of America 93, 9970-9974.

Davletova, S., Rizhsky, L., Liang, H., Shengqiang, Z., Oliver, D.J., Coutu, J., Shulaev, V., Schlauch, K., Mittler, R., 2005. Cytosolic ascorbate peroxidase 1 is a central component of the reactive oxygen gene network of Arabidopsis. Plant Cell 17, 268-281.

Dat, J., Vandenabeele, S., Vranová, E., Van Montagu, M., Inzé, D., Van Breusegem, F., 2000. Dual action of the active oxygen species during plant stress responses. Cellular and Molecular Life Sciences 57, 779-795.

Dat, J.F., Foyer, C.H., Scott, I.M., 1998. Changes in salicylic acid and antioxidants during induced thermotolerance in mustard seedlings. Plant Physiology 118, 1455-1461.

Drazic, G., Mihailovic, N., 2005. Modification of cadmium toxicity in soybean seedlings by salicylic acid. Plant Science 168, 511-517.

Durner, J., Klessig, D.F., 1996. Salicylic acid is a modulator of tobacco and mammalian catalases. Journal of Biological Chemistry 271, 2849228501.

Foyer, C.H., Noctor, G., 2005. Oxidant and antioxidant signaling in plants: a re-evaluation of the concept of oxidative stress in a physiological context. Plant, Cell and Environment 28, 1066-1071. 
Freeman, J.L., Garcia, D., Kim, D., Hopf, A., Salt, D.E., 2005. Constitutively elevated salicylic acid signals glutathione-mediated nickel tolerance in thlaspi nickel hyperaccumulators. Plant Physiology 137, 1082-1091.

Giannopolitis, C.N., Ries, S.K., 1977. Superoxide dismutase in higher plants. Plant Physiology 59, 309-314.

Heath, R.L., Packer, L., 1968. Photoperoxidation in isolated chloroplast I. Kinetics and stoichiometry of fatty acid peroxidation. Archives of Biochemistry and Biophysics 25, 189-198.

Hissin, P.J., Hilf, R., 1976. A fluorometric method for determination of oxidized and reduced glutathione in tissues. Analytical Biochemistry 74, 214-226.

Iannelli, M.A., Pietrini, F., Fiore, L., Petrilli, L., Massacci, A., 2002. Antioxidant response to cadmium in Phragmites australis plants. Plant Physiology and Biochemistry 40, 977-982.

Kang, G.Z., Wang, C.H., Sun, G.C., Wang, Z.X., 2003. Salicylic acid changes activities of $\mathrm{H}_{2} \mathrm{O}_{2}$-metabolizing enzymes and increases the chilling tolerance of banana seedlings. Environmental and Experimental Botany 50, 9-15.

Kang, H.M., Saltveit, M.E., 2002. Chilling tolerance of maize, cucumber and rice seedling leaves and roots are differentially affected by salicylic acid. Physiologia Plantarum 115, 571-576.

Law, M.Y., Charles, S.A., Halliwell, B., 1983. Glutathione and ascorbic acid in spinach (Spinacia oleracea) chloroplasts, the effect of hydrogen peroxide and of paraquat. Biochemistry 210, 899-903.

Lee, S., Petros, D., Moon, J.S., Ko, T.S., Goldsbrough, P.B., Korban, S.S., 2003. Higher levels of ectopic expression of Arabidopsis phytochelatin synthase do not lead to increased cadmium tolerance and accumulation. Plant Physiology and Biochemistry 41, 903-910.

Levine, A., Tenhaken, R., Dixon, R., Lamb, C., 1994. $\mathrm{H}_{2} \mathrm{O}_{2}$ from the oxidative burst orchestrates the plant hypersensitive disease resistance response. Cell 79, 583-593

Liang, Y.C., Chen, Q., Liu, Q., Zhang, W.H., Ding, R.X., 2003. Exogenous silicon $(\mathrm{Si})$ increases antioxidant enzyme activity and reduces lipid peroxidation in roots of salt-stressed barley (Hordeum vulgare L.). Journal of Plant Physiology 160, 1157-1164.

Lopez-Delgado, H., Dat, J.F., Foyer, C.H., Scott, I.M., 1998. Induction of thermotolerance in potato microplants by acetylsalicylic acid and $\mathrm{H}_{2} \mathrm{O}_{2}$. Journal of Experimental Botany 49, 713-720.

Metwally, A., Finkemeier, I., Georgi, M., Dietz, K.J., 2003. Salicylic acid alleviates the cadmium toxicity in barley seedlings. Plant Physiology 132, $272-281$.
Mittler, R., Vanderauwera, S., Gollery, M., Van Breusegem, F., 2004. Reactive oxygen gene network of plants. Trends in Plant Science 9, 490-496.

Mukherjee, S.P., Choudhuri, M.A., 1983. Implications of water stress-induced changes in the levels of endogeneous ascorbic acid and hydrogen peroxide in Vigna seedlings. Physiologia Plantarum 58, 166-170.

Norman, C., Howell, K.A., Millar, A.H., Whelan, J.M., Day, D.A., 2004. Salicylic acid is an uncoupler and inhibitor of mitochondrial electron transport. Plant Physiology 134, 492-501.

Pietrini, F., Iannelli, M.A., Pasqualini, S., Massacci, A., 2003. Interaction of cadmium with glutathione and photosynthesis in developing leaves and chloroplasts of Phragmites australis (Cav.) Trin. ex Steudel. Plant Physiology $133,829-837$.

Prasad, T.K., Anderson, M.D., Martin, B.A., Stewart, C.R., 1994. Evidence for chilling-induced oxidative stress in maize seedlings and a regulatory role for hydrogen peroxide. Plant Cell 6, 65-74.

Prasad, T.K., 1996. Mechanisms of chilling-induced oxidative stress injury and tolerance in developing maize seedlings: changes in antioxidant system, oxidation of proteins and lipids, and protease activities. Plant Journal 10, 1017-1026.

Rao, M.V., Paliyath, G., Ormrod, D.P., Murr, D.P., Watkins, C.B., 1997. Influence of salicylic acid on $\mathrm{H}_{2} \mathrm{O}_{2}$ production, oxidative stress, and $\mathrm{H}_{2} \mathrm{O}_{2}$-metabolizing enzymes (Salicylic acid-mediated oxidative damage requires $\mathrm{H}_{2} \mathrm{O}_{2}$ ). Plant Physiology 115, 137-149.

Schützendübel, A., Nikolova, P., Rudolf, C., Polle, A., 2002. Cadmium and $\mathrm{H}_{2} \mathrm{O}_{2}$-induced oxidative stress in Populus $\times$ canescens roots. Plant Physiology and Biochemistry 40, 577-584.

Schützendübel, A., Schwanz, P., Teichmann, T., Gross, K., LangenfeldHeyser, R., Godbold, D.L., Polle, A., 2001. Cadmium-induced changes in antioxidative systems, hydrogen peroxide content, and differentiation in scots pine roots. Plant Physiology 127, 887-898.

Schützendübel, A., Polle, A., 2002. Plant responses to abiotic stresses: heavy metal-induced oxidative stress and protection by mycorrhization. Journal of Experimental Botany 53, 1351-1365.

Yang, Z.M., Wang, J., Wang, S.H., Xu, L.L., 2003. Salicylic acid-induced aluminum tolerance by modulation of citrate efflux from roots of Cassia tora L. Planta 217, 168-174.

Zhao, Z.Q., Cai, Y.L., Zhu, Y.G., Kneer, R., 2005. Cadmium-induced oxidative stress and protection by L-Galactono-1,4-lactone in winter wheat (Triticum aestivum L.). Journal of Plant Nutrition and Soil Science 168, 759-763. 